\title{
The Quest of Quality and Accountability Standards of Accreditation of Teacher Education Programmes: A Meta-Analysis
}

\author{
Sadia Sadiq (Principal Author) \\ PhD Scholar - Faculty of Social Sciences Department of Education \\ International Islamic University Islamabad
}

\begin{abstract}
This paper is the meta- analysis of accreditation of teachers 'education programmes which deals with the accreditation process and initiatives regarding improvement of teacher education Programmes. Triangulation was attained through document analysis of NACTE and HEC initiatives along with thirty-one articles related to the international accreditation of Teacher education programmes. Thematic analysis has been completed with reference to accreditation of teacher education programs. Method of study was critically reviewing and analysis the accreditation practices in teacher education globally and nationally by comparing and contrast the twenty one number of researches, three survey reports along with their sample size and effect size for the aggregate effect. The findings show the gap between the scope of quality accreditation standards and dissimilar dealing with some of the indicators with orientation to its implication. Limitation of the study in particular area is the concern of missing data in multidimensional aspects of the research study and secondly model driven meta-analysis results are based on different sample, population and different sets of studies. Pakistani standards may be reviewed keeping in view the international standards of teacher education programmes accreditation. National accreditation council must have to set new targets to meet the international teacher education program goals, so monitoring and assessment of teacher education programmes must be proceeding regular bases, free of biases to encounter the quality accreditation of teacher education programs.
\end{abstract}

Keywords: Teacher Education, National Accreditation, Quality Assurance, Quality Standards.

DOI: $10.7176 / \mathrm{JEP} / 11-16-04$

Publication date:June 30th 2020

\section{Introduction}

The capacity development of teachers is considered a vital significant part of getting excellence in each field of life for any country. The technology, science, innovation, economics and generally training of each nation are corresponding the improvement of instructors' measures without exception. The excellence of teachers in educational institutions is regularly estimated by pre-set benchmarks, have been set up by each state, termed as quality levels. Meta-analysis is the main factors of the investigation which is being conceptualized. Metaanalysis study manages the measurable investigation which relates the outcomes of various logical research contemplates. Meta-Analysis can be made when there are complex logical research examines addressing a similar inquiry, with every single research revealing that hopes to have some level of fault. Today, most of the European and Asian countries have been established their own structures of quality assurance to meet the demands of globalization of higher education, while quality assurance and regulatory authorities assist governments to promote higher education for the sake of international competitiveness (Salmi, 2011; Hazelkorn, 2015). Many quality assurance organizations as Asia Pacific Quality Network (APQN), International Network for Quality Assurance Agencies in Higher Education (INQAAHE) and Council for Higher Education Accreditation (CHEA) etc. are focusing more to the impact of ranking on higher education (Hou, 2012).

Following the global trend, Pakistan has also established the Higher Education Commission (HEC) and the National Accreditation Council for Teacher Education (NACTE), which have established quality criteria of international standards for the assessment and evaluation of programs existing at higher education institutions to progress the excellence of faculty, infrastructure and research (Naeem \& Kayani 2014; Mirza, 2015).Compression is growing on the management to put attention to quality assurance, research integration, in teacher education. This particular mata analysis is carried out to regulate the accreditation standards for quality teacher education programmes and the preparedness of Pakistani universities for national and international accreditation of teacher education programmes

\subsection{Purpose of the Research}

Quality of teacher instruction can be advanced through the arrangement of basic facilities updated courses, on job trainings, upgradation of levels of qualification and initiatives taken by stakeholders to attainment up to the determined level of excellence, Malaysia and India are becoming the hub of quality teacher education programmes in Asia while Pakistan is standing far behind. We have the potential infrastructure and human 
resource capital needed for the revival of quality of teacher education programmes. This particular meta-analysis providing the outline of theocratical and methodological framework for the interpretation to examine the shaping of discourse of the Accreditation of teacher education programmes standards, procedures and policy document to determine the preparedness of the teacher education departments of Pakistani universities for national and international accreditation.

\subsection{Research Questions}

The following research questions formulated from the objectives.

1. To what extent the departments of education are following the guidelines given by NACTE for teacher education programs' accreditation.

2. What is the difference between National Accreditation standards practices for teacher education and international standards?

3. How Pakistani accreditation standards for teacher education programs can be improved?

\subsection{Research Objectives}

Following are the objectives of the meta-analysis:

1. To determine the quality indicators of NACTE for accreditation of teacher education programmes.

2. To compare national accreditation standards with international accreditation standards of teacher education.

3. To suggest improving Pakistani indicators for quality teacher education accreditation.

\subsection{Limitations}

Limitation of the study in particular area is the concern of missing data in multidimensional aspects of the research study and secondly model driven meta-analysis results are based on different sample, population and different sets of studies. The study was limited to the analysis of 5 countries 'accreditation practices.

\section{Review of Literature}

The basics to achieve vital quality educational objectives, quality assurance of teacher education programs is needed, such as proper infrastructure (building, equipment and facilities), teachers' qualification, research capacity, and facilitative leadership empowering faculty and staff (Arif, Ilyas \& Hameed, 2013;2017). Similarly, in order to ensure the excellence programs of teacher education it is important to set some standards to conduct modifications in teacher education, that can only be attainable for establishing accreditation bodies. Here, the question Knight (2014) arises that how much awareness has been created among faculty and management for the utility and importance of taking these steps in the education departments of Pakistani universities.

The organisations and systems which deliver cross-border programs or developments are conditioned to be registered, recognized or licensed from both receiving and sending countries. Therefore, quality assurance and accreditation are the important requirements to gain the benefits of international world (Spilka \& Dobson, 2015). There is also a deficiency of capacity and radical will in many countries to develop a regulatory framework for the evaluation of excellence of programs of teacher education accreditation (Rector \& Beck, 2012). Same problems are faced by Pakistani universities as well (Nadeem, Abbas \& Javed, 2014). Higher Education Commission in Pakistan serves the purpose of both quality assurance, accountability and accreditation of teacher education. One of its significant objectives is also setting parameters for quality teacher education programmes and ranking in order to encounter international standards (Nadeem et al., 2014; Shahid, Wahab \& Ahmed, 2016).

The quality of programmes of teacher education in Pakistan are relatively lower as comparison to the advanced countries; now, seriously planned effort is needed for quality assurance and quality enhancement (Akhtar, 2011; Jabeen, 2010; Dilshad \& Iqbal, 2010; Khan, 2011; Arif et al., 2013; 2017). Many efforts in this regard have been made by the government of Pakistan, such as in 2006 a National Assessment and Accreditation Council was established and Education Sector Reform (ESR) and National Education Assessment System (NEAS) were implemented to improve teachers' qualification and educators' cadre and to assess and monitor the quality of teaching in the institutes of teachers' education.

Findings of Dilshad and Iqbal (2010) about the accredited indicators of teacher education programs in Pakistan specified the crucial need of the implementation of accredited system in the Pakistani context which give rise to in the development of standards for teachers' education (NACTE 2009) by the Accreditation Council of Teacher Education (ACTE). A self-governing body (NACTE) has been set up by HEC through notification of Federal Government in the gazette of Pakistan to guarantee and improve the excellence of teachers' education programs. The task of NACTE is to ensure the accreditation of excellence of teachers' education programs through interior and exterior professional and academic assessments for accreditation and also to provide support for the facilitation of teachers' education intended for their capacity building and self-improvement.

Universities must create dynamic strategies for their teacher education programmes to study overseas as well as having foreign students on their campuses, either through an exchange program or through regular 
admissions (Bhandari \& Blumenthal, 2013; Altbach, 2015). Rizescu (2013) Change gurus like Fullan (2015) expound that resistance could not be overcome unless teachers willingly assume their role as "change agents." Readiness comes before implementation. Although there are many blind attempts at the implementation of quality and accreditation programs going on in education departments of various universities of Pakistan, however, nothing fruitful has been achieved yet. Only seven universities of Pakistan have qualified to be included in first 1000 universities of the world and only two of them are included in the first 500 (Academia, 2019). What is lacking is the will, motivation, resources and/or policy, which can make things smoother for Pakistani universities to qualify for better ranks in international rankings. Indeed, getting local accreditation is the first step, therefore, this research strives to determine how effectively this step is being taken by the education departments of universities in Pakistan for process of accreditation teachers' education programs

NACTE has established Standards for the Teacher Education Programs' Accreditation for Sustainable Development (ESD) (Mirza, 2015). This framework comprises seven National Accreditation Standards (NAS). A conceptual framework is mandatory to be adopted as an initial accreditation requirement and subsequently to implement the seven standards for long-term planning. These standards are used to measure and evaluate the quality through dividing it into further measurable indicators. These standards have been created through the coordination of NACTE, HEC and USAID's STEP program (Huma, 2013). NACTE evaluates the teachers' evaluation programs provided by public universities, private institutions and foreign affiliated institutions, since all teacher education programs are mandatory for accreditation. The Pakistani government is keen for improvement of higher education and especially teacher education in Pakistan and it has taken various valuable initiatives in this regard. Hence, it is important to know where these steps have led us today

\section{METHOD}

The study is mixed method in nature with specific orientation to meta-analysis. Most of the studies used descriptive and comparative analysis (qualitative research-case studies, demographic surveys) four studies used ANOVA, mean percentage. A detailed study analysis has been made of pertinent documents, research articles, review reports concentrating the accreditation of teacher education programmes based on set indicators and improving amendments regarding its standards the quality standards of HEC, NACTE and International council for teacher education.

\subsection{Data Source and Searches}

The primary source of this meta-analysis based on accreditation of teacher education programmes were research articles synthesis, reported the sorts of factors and kind of variables and practices. Meticulous terminology, Keywords in addition seven electronic data basses were searched. These sources were supplemented by searches of more than 17 journals publishing teacher education-related investigation. The electronic data base explored for the candidate study were ERIC, ProQuest, Central, directory of open Access Journals, PsyInfo, Open Access Journal search engine, and Google scholar

\subsection{Study Selection}

Four types of researches were included for study selection. The first one was the study reports that were generally met the criteria for candidate study topic. Second type related to research articles which comprised effects from solo researches, that required prospective meta-analysis. The third one related to the national studies based on accreditation of teacher education. The fourth one conference presentations based on current practices. The researcher used the Themes emerged in the extensive literature review through directed content analysis of the related literature and NACTE's guidebook. The findings were discussed in the light of global literature and theories of internationalization and globalization. Finally, conclusions were drawn about the collective understanding of the phenomenon of accreditation and internationalization by the faculty of education departments in Pakistani universities and their willingness to learn and continue with this phenomenon to compete in international market of higher education.

\subsection{Data Extraction}

Four-tiered research strategy has been used to locate the potential meta-analysis, research synthesis separately precise key terminologies in distinct searches (e.g. Meta-analysis, Accreditations, programs of teacher education).The another tiered searched including, term meta-analysis with combination of all possible specific type of terms like quality assurance standards, teacher education, international accreditation until the required search studies found. Both first and second tier's results exploration were found with significance to confirm the maximum matches with the required terms.

The $3^{\text {rd }}$ tier search include both remote and electronic of possible sited research analyses, research reports and related quality teacher education articles for meta-analysis were to categorize added exploration blended researches not found in previous two tiers. 
Fourth tier included bibliographies and references were to locate by searches of Google and Google scholar. The searches for research synthesis both national and international reports, journal articles and conference presentations, web reports, included the selected theme that met the inclusion criteria of the meta-analysis was adopted.

\subsection{Data Analysis}

The data was collected, analyzed and interpreted through extensive review and critical analysis of the documents by indicating their reference placement along with statistical techniques by using mean effect size. In that conditions where impact sizes or results were accounted for utilizing different records or measurements, they were changed over to mean difference effect sizes utilizing, for the most part, suggested transformation techniques. In certain examples, effect sizes have been assessed from accessible data in the exploration surveys. In various research reports, effect sizes for the group comparison were accounted. In situations where results were accounted for as not prominently significant, the impact sizes for those practice correlations were thought to be zero preceding amassed results were compiled.

Table 3.4.1: Variables focused in Accreditation Standard of Teacher Education Programmes

\begin{tabular}{lc}
\hline \multicolumn{1}{c}{ Variables } & $\begin{array}{c}\text { Research Refence } \\
\text { Sources }\end{array}$ \\
\hline $\begin{array}{l}\text { Type of Teacher Degree (Associate degree, Bachelor's degree, master's Degree, } \\
\text { M.Phil. degree and Doctoral degree) }\end{array}$ & $\mathbf{2 , 4 , 6 , , 7 , 1 1 ,}$ \\
$\begin{array}{l}\text { Types of Teacher preparation Programs (extended degree programs, honors } \\
\text { degree programs, bachelor's degree programs and integrated programs and } \\
\text { blended degree programs) }\end{array}$ & $\mathbf{1 , 2 , 6 , 7 , 1 0 , 1 1 , 1 2}$ \\
$\begin{array}{l}\text { Types of Teacher Certification (Professional teacher certificates, National Board } \\
\text { certificates, technical Teaching Certificate, teach for America Certification, }\end{array}$ & $\mathbf{1 3 , 1 5 , 2 1 , 2 2}$ \\
$\begin{array}{l}\text { Alternative teaching certificates) } \\
\text { Faculty Instructional Practices (faculty coaching, just-in-time training, Faculty } \\
\text { monitoring) }\end{array}$ & $\mathbf{1 2 , 1 3}$ \\
$\begin{array}{l}\text { Types of Field experiences (Student teaching, Lesson practicums, } \\
\text { Microteaching, simulated teaching) }\end{array}$ & $\mathbf{7 , 1 2 , 1 3}$ \\
$\begin{array}{l}\text { Methods of Course Delivery (Distance Education courses, blended courses, } \\
\text { personalized instruction-based courses }\end{array}$ & $\mathbf{1 1 , 1 2 , 1 7 , 2 3 , 2 7 , 2 8}$ \\
Web and online based Instructions (Online teaching, CAI method of & $\mathbf{2 , 1 3 , 2 6 , 2 7 , 2 8}$ \\
instructions, virtual reality-based instructions) &
\end{tabular}

Table.3.4.2: Meta-Analysis of Various aspects of Teacher Education Programs in different studies

\begin{tabular}{|c|c|c|c|c|}
\hline Variables & $\begin{array}{l}\text { No. Research } \\
\text { studies }\end{array}$ & $\begin{array}{l}\text { Sample } \\
\text { Size }\end{array}$ & $\begin{array}{ll}\text { No. } & \text { of. } \\
\text { Effects }\end{array}$ & $\begin{array}{l}\text { Mean Effect } \\
\text { Size }\end{array}$ \\
\hline Teaching Qualification & 14 & 3440 & 21 & 0.33 \\
\hline Teacher preparation programs & 08 & +1385 & 8 & 0.04 \\
\hline Teaching Certificate & 7 & 1243 & 44 & 0.11 \\
\hline $\begin{array}{l}\text { Quality of Content of teacher Education } \\
\text { Programs }\end{array}$ & 6 & 1066 & 6 & 0.23 \\
\hline $\begin{array}{l}\text { Technology integration with teacher } \\
\text { education }\end{array}$ & 11 & +2732 & 66 & 0.53 \\
\hline Teaching Practice & 4 & +550 & 11 & 0.78 \\
\hline Quality standards of Teacher Education & 08 & 1385 & 8 & 0.04 \\
\hline
\end{tabular}

\section{META- ANALYSIS RESULTS}

The findings of meta-analysis study reveal that the data was organized into the following themes and subthemes practices for further exploration (Table 3.4.1) and secondly rank order size of effects of various types of elements of teacher education. Number of studies, sample sizes, effect size mean difference effect size for aggregate result. those articles which were not indicated the sample size the researcher indicated the plus sign which shows the sample size may be larger than we were able to determine. (Table 3.4.2) The data was categorized under two main themes and several subthemes answering the research questions. The first theme was about following the guidelines of NACTE (local Pakistani accreditation system) and the second theme was about the International teacher education accreditation in teacher education programmes. Moreover, that is significant toward the local accreditation first; international accreditation can be pursued only afterwards. 


\section{FINDINGS:}

\section{Theme 01: Following NACTE guidelines of Accreditation of programs (Teacher Education)}

NACTE assesses the department of education according to certain criterion for which the NACTE guidelines has to be followed.the study reveals that following aspects of teacher education programmes in Pakistan.

1. Only few programmes has been accredit in 28 departments of Education which is almost made of $(48 \%)$ 13 out of 27 studies of the whole country universities and teacher education programmes.

2. Findings revealed that $33 \%$ ( 7 out of 21 studies) of faculty informed that their department are undergoing the process of accreditation for their teacher education programmes.

3. $81 \%$ of the faculty members (18/22 of studies) know about the qualification and certification level upgradation of teacher education programmes in the teacher education.

\section{Teaching Degree Qualification}

Fourteen meta-analysis reports and two articles review found that degrees for teacher education is focused element in accreditation of teacher education programmes as associate degree, bachelor's degree, Master's degree and Doctoral degree in order to quality enhancement of teacher education programmes

\section{Preparation Programmes}

Six researches and only two survey was found of three years comparison of extended teacher preparation programs were found. These surveys were based on measurement of professional development and extended preparation programmes

\section{Teacher Certification}

Eighteen research articles were found which included the comparison of teachers' certification and teaching quality

\section{Methods of Content Delivery in teacher Education Programmes}

Fourteen studies were located which indicated different methods of course delivery is being used in teacher education programmes included: distance education courses, blended courses, face-to-face courses, audio tutorial courses etc.

\section{Technological Integration and E-learning Instructions}

Eleven meta-analysis were located that are being used in teacher education programmes as an accredited quality standard e.g. ICT, Computer assisted instructions, Internet based instructions and virtual reality instructions in teacher education programmes.

\section{Faculty Instructional Practices}

Eight meta-analysis found the judgment of quality of faculty instructional practices including faculty coaching, consultative feedback and faculty monitoring in teacher education programmes.

\section{Student of teacher, Teaching Practice}

Four research studies and two conference presentations found the assessment of different types of teaching field quality and teaching practices. The survey also included the information about teaching practices involved the comparison of 10 or more weeks with little student teaching or with no teaching practice.

\section{Quality of teacher Education Programmes}

Seven research articles and one survey were founded to meta-analysis of quality of teacher education programmes included, quality of teacher practitioners, classroom instructional practices, quality of content related to pre-service and in-service teaching programmes.

Theme.2. The difference between national accreditation standards for teacher education and international standards

The study review reveals that there is existed discrepancies in diverse standards and indicators of accreditation of teacher education programmes. Some countries have different numbers of standards for accreditation of teacher education programmes. The findings are as following:

1. In Canada there are 34 standards for accreditation of teacher education have been following.

2. India is following 75 quality standards for accreditation of teacher education programmes.

3. Australia is following only 3 standards for accreditation of teacher education

4. USA is following 07 standards in teacher education, which remain 06 after reduction.

5. Pakistan, NACTE is followed 09 standards for teacher education.

\section{DISCUSSION}

The quality of any education system is directly interconnected with the quality of its teacher education programmes. Lack of quality teachers will be the cause of poor education system of any country. So, the quality of teacher and teacher education programmes must be examined in order to its accreditation of the standards. It is crucial to implement skill development programmes in teacher education to move with the global pace of progress. Standardized standards must be followed for assessment and evaluation which emphasis on quality of teacher education programmes. Huma (2013)

University has always been an international institution claiming its global rights for students and faculty. 
After the Second World War, the creation of nation-states halted this process for some time but the recent revolution in ICTs and global media has broken all borders and barriers (Henderson, Barnett \& Barnett, 2017). Quality assurance and internationalization are the basic objectives for the institutes of higher education. In international market, accreditation and ranking of universities are getting more and more popular which is affecting the perception of all stakeholders and beneficiaries of the higher education sector (Altbach, 2015; Knight, 2015). All universities around the world need to pay close attention to it; opportunities for accreditation and internationalization must be available to education departments as well because the quality of the whole education system depends upon teacher quality (Siddiqui, 2012).

\section{CONCLUSION}

The primary aim of this meta-analysis was to identify the accreditation and set standards of quality programs of teachers' education with regarding following quality assurance activities of NACTE suggest that teacher education departments of Pakistani universities are not serious in getting NACTE accreditation. A very negligible percentage of faculty $(18 \%)$ expressed that all programs offered by their departments are not accredited. Neither did the faculty express any enthusiasm about getting involved in NACTE accreditation, nor did they find any relevant activities initiated by their university leadership. However, the faculty expressed willingness to learn more about quality assurance, accreditation, and its benefits for their departments.

The findings of this research conclude that education departments of Pakistani universities are not keenly following the directions for quality assurance and accreditation by NACTE. The departments have taken few steps for industry academia linkages or external relations. It is strange that many universities and departments have no association or Memorandum of Understanding (MOUs) with public and private schools to send their students for teaching practice. Similarly, the departments are not involved in initiating student and faculty exchange programs. Most of them have no alumni network or endowment funds to regulate their expenses.

\section{RECOMMENDATIONS}

Teachers and teacher education play a crucial role for the upgrading of the overall quality of instruction and the government should soften the plans for coordination of departments with other national institutions and also should take steps with other teacher education organization to develop coordination with international departments. To save their future, the education departments will have to take any or all of the following measures as suggestions.

1.Pakistan, NACTE may review its present professional standards for quality teacher education due to discrepancies in many standards.

2.Pakistani teacher education programs may adapt current global practices for better quality of teacher education programmes such as industry academia linkage, and MoU signing with public or private schools.

3.The teacher education stakeholders must include up to date syllabus and subjects in their teacher education programmes and encourage research-based project for quality improvement.

4. Strict standardized monitoring and accredited criteria and standards must be followed.

5. Punishment and reward must be added up to bring the quality in teacher education programmes.

6.This meta-analysis suggests the harmonized scope of the quality indicators of accreditation of teacher education, updating the indicators in Pakistani educational context.

\section{References.}

Altbach, P. G. (2015). Higher education and the WTO: Globalization run amok. International Higher Education, $23,2-4$.

Altbach, P. G. (Ed.). (2014). International higher education: An encyclopedia (1st ed., Vol. 1). London: Routledge.

Alfieri, L.; Brooks, P.J.; Aldrich, N.J.; (2011) Tenenbaum, H.R. Does discovery-based instruction enhance learning? J. Educ. Psychol, 103, 1-18. [Google Scholar] [CrossRef][Green Version]

Akarsu, B.; Kaya, H. (2012), Redesigning effective methods courses: Teaching pre-service teachers how to teach. Electron. J. Sci. Educ. 16, 1-16. [Google Scholar]

Arif, S., Ilyas, M. \& Hameed, A. (2013). Student satisfaction with services in private universities of Pakistan: The impact of leadership. Total Quality Management (TQM), 25(4), 399-416.

Arif, S., Ilyas, M. \& Hameed, A. (2017). Using structure equation modeling to construct student satisfaction models for private universities of Pakistan. Journal of Quality and Technology Management, 14(2), 39- 73.

Burns, R.W.; Jacobs, J.; Yendol-Hoppey, D. (2016), The changing nature of the role of the university supervisor and function of preservice teacher supervision in an era of clinically-rich practice. Action Teach. Educ. 38, 410-425. [Google Scholar] [CrossRef]

Bhandari, R. \& Blumenthal, P. (2013). International students and global mobility in higher education: National 
trends and new directions. International Studies, 1(11), 316-317.

Blandford, A. E. (2013). Semi-structured qualitative studies. In M. Soegaard and R. Dam (Eds.), The Encyclopedia of human-computer interaction. Denmark: Interaction Design Foundation.

Creswell, J. W. (2012). Educational research: Planning, conducting, and evaluating quantitative and qualitative research. Boston, MA: Pearson Education.

Cochran-Smith, M.; Villegas, A.M.; Abrams, L.W.; Chavez-Moreno, L.C.; Mills, T.; Stern, R (2016). Research on teacher preparation: Charting the landscape of a sprawling field. In Handbook of Research on Teaching, 5th ed.; Gitomer, D.H., Bell, C.A., Eds.; American Educational Research Association: Washington, DC, USA,. [Google Scholar]

De Wit, H., \& Beelen, J. (2014, May 2). Reading between the lines: Global internationalization survey. University World News, 318. Retrieved August 30, 2016, from http:/www.universityworldnews.com

Dilshad, M., \& Iqbal, H. M. (2010). Quality indicators in teacher education programs. Pakistan Journal of Social Sciences, 30(2), 401-411.

Goldhaber, D.; Liddle, S. (2012).The Gateway to the Profession: Assessing Teacher Preparation Programs Based on Student Achievement; CALDER: Washington, DC, USA, [Google Scholar]

Greenberg, J.; Pomerance, L.; Walsh, K. (2011) Student Teaching in the United States; National Council on Teacher Quality: Washington, DC, USA. [Google Scholar]

Henk, W.A.; Stahl, N.A. (2018) A meta-analysis of the effect of notetaking on learning from lecture. College reading and learning assistance. In Proceedings of the Annual Meeting of the National Reading Conference, St. Petersburg Beach, FL, USA, 20 November; Available online: https://files.eric.ed.gov/fulltext/ED258533.pdf

Labaree, D.F. An uneasy relationship: (2010) The history of teacher education in the university. In Handbook of Research on Teacher Education: Enduring Questions in Changing Contexts Research, 3rd ed.; CochranSmith, M., Feiman-Nemser, S., McIntyre, D.J., Eds.; Routledge: New York, NY, USA; pp. $290-306$. [Google Scholar]

Mirza, M. S. (2015). Institutionalizing ESD standards in teacher education programs: Case of national accreditation council for teacher education, Pakistan. Applied Environmental Education \& Communication, 14(2), 97-104.

Moon, B. (2016) The issues and tensions around teacher education and training in the university. In Do Universities Have a Role in the Education and Training of Teachers? An International Analysis of Policy and Practice; Moon, B., Ed.; Cambridge University Press: Cambridge, UK, pp. 1-18. [Google Scholar]

Nadeem, M. S., Abbas, Q., \& Javed, U. (2014). In quest to quality: Are we on the right path? International Proceedings of Economics Development and Research, 70, 140. Rector,

N. A., \& Beck, A. T. (2012). Cognitive behavioral therapy for schizophrenia: An empirical review. Journal of Nervous and Mental Disease, 189, 278-287

Hoppey, D.; Yendol-Hoppey, D. (2018). Outcomes of High-Quality Clinical Practice in Teacher Education; (Eds.) Information Age Publishing: Charlotte, NC, USA,. [Google Scholar]

Saracho, O.N. (2013) Early childhood teacher preparation programmes in the USA. Early Child Dev. Care, 183, 571-588. [Google Scholar] [CrossRef]

Shahid, H., Wahab, Z., \& Ahmed, S. A. (2016). Factor analysis to explore the indicators of quality assurance mechanism on higher educational institutions in Pakistan. Journal of Basic and Applied Sciences, 12, 146-154.

Shin, J. C., \& Toutkoushian, R.K. (2011). The past, present, and future of university rankings. In J. C. Shin, R. K. Toutkoushian, \& U. Teichler (Eds.), University rankings: Theoretical basis, methodology and impacts on global higher education (pp. 1-16). Dordrecht, Netherlands: Springer.

Siddiqui, S. (2010). Rethinking education in Pakistan: Perceptions, practices, and possibilities. Lahore: Paramount.

Spilka, M. J., \& Dobson, K.S. (2015). Promoting the internationalization of evidence-based practice: Benchmarking as a strategy to evaluate culturally transported psychological treatments. Clinical Psychology: Science and Practice, 22(1), 58-75.

Theeboom, T.; Beersma, B.; \& van Vianen, A.E.M. (2014), Does coaching work? A meta-analysis on the effects of coaching on individual level outcomes in an organizational context. J. Posit. Psychol. 9, 1-18. [Google Scholar] [CrossRef]

Venkatesh, P. (2013). Accreditation as a benchmark of quality sustenance in higher education: A review of quality assurance in Indian university system. Nitte Management Review, 7(1), 59-67.

Warwick, P., \& Moogan, Y. J. (2013). A comparative study of perceptions of internationalization strategies in UK universities. Compare: A Journal of Comparative and International Education, 43(1), 102-123

Zeichner, K. (2016) The changing role of universities in US teacher education In Do Universities Have a Role in the Education and Training of Teachers? An International Analysis of Policy and Practice; Moon, B., Ed.; Cambridge University 